\title{
Manganese-salen catalyzed oxidative benzylic chlorination
}

\author{
SHEULI SASMAL, SUJOY RANA, GOUTAM KUMAR LAHIRI* and DEBABRATA MAITI* $\mathbb{}$ \\ Department of Chemistry, Indian Institute of Technology Bombay, Powai, Mumbai, Maharashtra 400 076, India \\ E-mail: lahiri@chem.iitb.ac.in; dmaiti@chem.iitb.ac.in
}

MS received 5 April 2018; revised 28 May 2018; accepted 8 June 2018; published online 5 July 2018

\begin{abstract}
Metalloporphyrins are well-known to serve as the model for mimicking reactivities exhibited by cytochrome P450 hydroxylase. Recent developments on selective $\mathrm{C}-\mathrm{H}$ halogenation using Mn-porphyrins provided the way for understanding the reactivity as well as mechanism of different halogenase enzymes. In this report, we demonstrated a method for benzylic C-H chlorination using easily prepared $\mathrm{Mn}$ (salen) complex as the catalyst, which shows a complementary reactivity of $\mathrm{Mn}$-porphyrins. Here, $\mathrm{NaOCl}$ has been used as a chlorinating source as well as the oxidant. Efforts towards understanding the mechanism suggested the formation of the high-valent $\mathrm{Mn}(\mathrm{V})=\mathrm{O}$ species which is believed to be the key intermediate to conduct this transformation.
\end{abstract}

Keywords. High-valent manganese; salen; hypochlorite; benzylic chlorination.

\section{Introduction}

Nature has developed several fascinating enzymatic path to incorporate hydroxyl or halogen group oxidizing specific $\mathrm{C}-\mathrm{H}$ bond of bioactive molecules. ${ }^{1}$ In this perspective, heme-dependent enzymes such as cytochrome P450, haloperoxidase are known to accomplish hydroxylation and halogenation in natural molecules ${ }^{2}$ where a high-valent iron-oxo species is believed to be the active intermediate. ${ }^{1,3}$ In the realm of practical chemistry, the feasibility of halogenation viz. chlorination of benzylic substrates is a bit challenging because of the competitive ring halogenation or over-halogenation. The reported procedures for benzylic $s p^{3} \mathrm{C}-\mathrm{H}$ chlorination uses reagents such as free $\mathrm{Cl}_{2},{ }^{4} \mathrm{PCl}_{5},{ }^{5}$ aquaregia, ${ }^{6}$ $\mathrm{Et}_{4} \mathrm{NCl},{ }^{7}$ benzyltrimethylammonium tetrachloroiodate $\mathrm{BTMAICl}_{4},{ }^{8}$ nano-Ag/AgCl, ${ }^{t}{ }^{t} \mathrm{BuOCl},{ }^{10}$ etc., which are explosive, toxic as well as corrosive. Further, most of the cases require irradiation or heating resulting in poor chemoselectivity and regioselectivity. Additionally, use of nano- $\mathrm{Ag} / \mathrm{AgCl},{ }^{9}{ }^{t} \mathrm{BuOCl}^{10}$ for chlorination purpose produced oxygenated side product in major quantity. To address these issues, researchers designed various metalloporphyrin as biocatalyst which successfully served as a model compound to mimic the reactivities of cytochrome P450 over the past few decades. ${ }^{11}$ Among

\footnotetext{
*For correspondence
}

the various known metalloporphyrins, Mn-porphyrins have been known for its incredible reactivity towards the oxidation of both saturated and unsaturated hydrocarbons including oxidation of complex molecules. ${ }^{12}$ Recently, Mn-porphyrin complexes had also shown its ability to catalyze carbon-halogen bond formation (Scheme 1a). ${ }^{13}$ Pertaining to chlorination, in 2010, J. T. Groves and co-workers demonstrated Mn-porphyrin mediated $\mathrm{C}-\mathrm{H}$ bond chlorination of simple hydrocarbons which depicted only single instance of benzylic chlorination. ${ }^{13 a}$ Herein, we are interested to investigate the less explored domain of benzylic $s p^{3} \mathrm{C}-\mathrm{H}$ chlorination using a manganese salen complex as catalyst (Scheme 1b). This catalyst was mainly developed by Jacobson/Katsuki for enantioselective epoxidations. ${ }^{14} \mathrm{It}$ has also been utilized effectively towards other carbonheteroatom bond formations. ${ }^{15}$ The attractive features of these catalysts lie in their easy synthesis and facile structural modifications.

Chlorinated benzylic compounds are very important class of substrates since their chloromethyl group can be easily converted to other group like hydroxymethyl, cyanomethyl, etc. ${ }^{16}$ Further, various bioactive molecules, such as ibuprofen, vitamin $\mathrm{E}$ analogues like steroids, terpenoids including various amino acids contain benzylic position that are amenable for late-stage diversification (Figure 1). 
a Previous work:

$\mathrm{R}-\mathrm{H}$

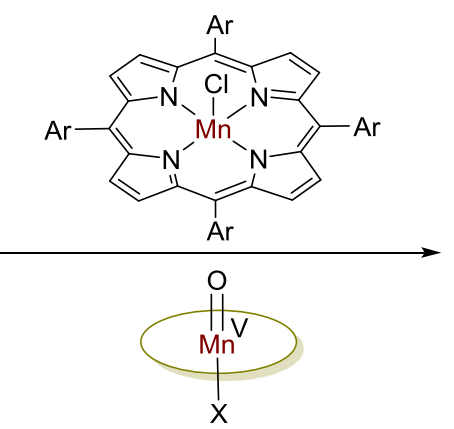

b This work:

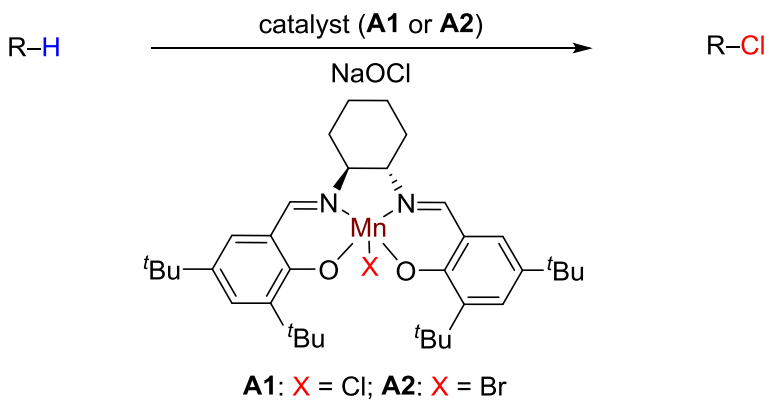

Scheme 1. (a) Mn-porphyrine catalyzed C-H halogenation. (b) $\mathrm{Mn}$-salen catalyzed benzylic $\mathrm{C}-\mathrm{H}$ chlorination.

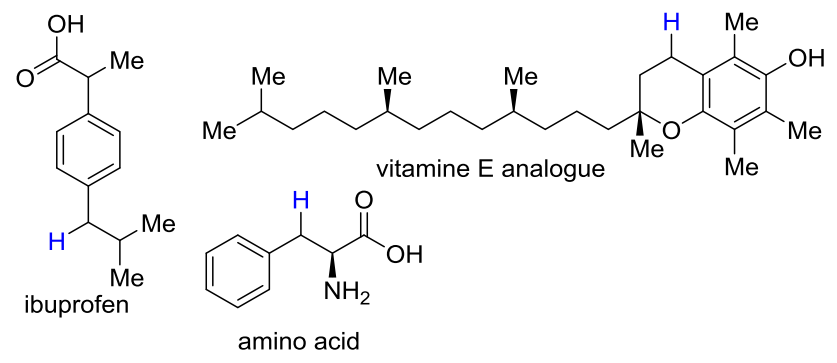

Figure 1. Examples of bioactive molecules containing benzylic C-H bond.

\section{Experimental}

\subsection{Materials and instrumentation}

Unless otherwise stated, all of the reactions were carried out at room temperature in a $10 \mathrm{~mL}$ screw-capped reaction tube under $\mathrm{N}_{2}$ atmosphere. $\mathrm{NaOCl}$ was purchased from Sigma Aldrich. Other necessary Chemicals and solvents were purchased from Sigma Aldrich, Merck, Alfa Aesar and Spectrochem. A gradient elution using petroleum ether and ethyl acetate was performed, based on Merck Aluminum TLC sheets (silica gel 60F254). Products were characterized by ${ }^{1} \mathrm{H}$ and ${ }^{13} \mathrm{C}$ NMR spectroscopy, gas chromatography (GC) and gas chromatography-mass spectrometry (GC-MS). $n$-decane was used as standard. NMR spectra were recorded either on a Bruker $500 / 400 \mathrm{MHz}$ or on a Varian $400 \mathrm{MHz}$ instrument. Copies of the ${ }^{1} \mathrm{H},{ }^{13} \mathrm{C}$ spectra are included in Supporting Information. All ${ }^{1} \mathrm{H}$ NMR spectra were reported in units of parts per million (ppm) and measured relative to the signals for residual chloroform $(7.26 \mathrm{ppm})$ in a deuterated solvent, unless otherwise stated. All ${ }^{13} \mathrm{C}$ NMR spectra were reported in ppm relative to $\mathrm{CDCl}_{3}$ (77.23 ppm), unless otherwise stated, and all were obtained with ${ }^{1} \mathrm{H}$ decoupling. All the products were analyzed by GC-MS. GC-MS was performed on a Thermo Scientific ISQ QD Mass Spectrometer attached with Thermo Scientific TRACE 1300 gas chromatograph using an HP-5ms capillary column $(30 \mathrm{~m} \times 0.25 \mathrm{~mm} \times 0.25 \mu \mathrm{m}$, J\&W Scientific) with helium as the carrier gas All GC analyses were performed on an Agilent 7890A GC system with a flame ionization detector using a J\&W DB-1 column $(10 \mathrm{~m} \times 0.1 \mathrm{~mm}$, i.d.). UV-Vis studies were performed in Agilent 8453 diode array based UV-Vis Spectrophotometer. ESI-MS spectra were performed in Bruker QTOF ESI-MS instrument. First order rate constants $(k 1)$ were calculated based on non-linear exponential fit in OriginPro8 software. Single crystal of complex A2 was diffracted in Rigaku X-ray single crystal diffractometer. The EPR measurements were carried out with an X-band (9.5 GHz) Bruker EMX Plus at $100 \mathrm{~K}$.

\subsection{Synthesis of salen ligand $\left(\mathrm{H}_{2}\right.$ Salen $)$}

Derivative of Salisaldehyde (2 equiv.) as solid was added in portions to absolute ethanol solution of diamine derivative. The reaction mixture was heated to reflux for an hour under nitrogen atmosphere and then cooled to room temperature. ${ }^{17}$ The yellow colored product was then collected by filtration washed with cold ethanol and dried under vacuum.

2.2a N,N-bis(3,5-di-tert-butylsalicylidene)-1,2-cyclohexanedi-amine: ${ }^{1} \mathrm{H} \mathrm{NMR}\left(500 \mathrm{MHz}, \mathrm{CDCl}_{3}\right) \delta 13.70$ (s, $2 \mathrm{H}), 8.29(\mathrm{~s}, 2 \mathrm{H}), 7.30(\mathrm{~d}, J=2.5 \mathrm{~Hz}, 2 \mathrm{H}), 6.98(\mathrm{~d}, J=$ $2.5 \mathrm{~Hz}, 2 \mathrm{H}), 5.04-4.91(\mathrm{~m}, 2 \mathrm{H}), 3.35-3.29(\mathrm{~m}, 2 \mathrm{H}), 1.94(\mathrm{~d}$, $J=14.5 \mathrm{~Hz}, 2 \mathrm{H}), 1.90-1.84(\mathrm{~m}, 2 \mathrm{H}), 1.73(\mathrm{~d}, J=11.0 \mathrm{~Hz}$, $2 \mathrm{H}), 1.50-1.45(\mathrm{~m}, 2 \mathrm{H}), 1.41(\mathrm{~s}, 18 \mathrm{H}), 1.23(\mathrm{~s}, 18 \mathrm{H}) .{ }^{13} \mathrm{CNMR}$ $\left(101 \mathrm{MHz}, \mathrm{CDCl}_{3}\right) \delta 166.0,158.2,140.0,136.5,126.9,126.2$, 118.0, 72.6, 35.1, 34.2, 33.4, 31.6, 29.6, 24.5.

\subsection{Synthesis of $\mathrm{Mn}$ (salen) complex $\left(\mathrm{Mn}^{I I I}\right.$ $($ salen $) X)^{17}$}

$\mathrm{H}_{2}$ salen ligand $(1.6 \mathrm{mmol})$ in $10 \mathrm{ml}$ of toluene was added to a suspension of $\mathrm{Mn}(\mathrm{OAc})_{2} \cdot 4 \mathrm{H}_{2} \mathrm{O}$ (3 equiv., $5 \mathrm{mmol}$ ) in $20 \mathrm{~mL}$ of boiling ethanol. Then the reaction mixture was refluxed overnight under nitrogen. After passing a stream of air through the reaction mixture. $20 \mathrm{~mL}$ saturated aqueous $\mathrm{NaCl}$ or $\mathrm{KBr}$ solution was added under vigorous stirring and the reaction mixture was allowed to cool at room temperature. After addition of $100 \mathrm{~mL}$ of toluene and $20 \mathrm{~mL}$ $\mathrm{CH}_{2} \mathrm{Cl}_{2}$, the organic layer was extracted with water and saturated $\mathrm{NaCl}$ solution. Then, it was dried with $\mathrm{Na}_{2} \mathrm{SO}_{4}$. Then the solvent was evaporated under reduced pressure. The product was dissolved in $\mathrm{CH}_{2} \mathrm{Cl}_{2}$ and then collected by filtration as a brown powder and dried under vacuum. The complex was characterized by X-ray crystallography (A2), ESI-MS 
study $\left(\mathrm{m} / \mathrm{z}=599.3\right.$ for $\left.\mathrm{C}_{36} \mathrm{H}_{52} \mathrm{MnN}_{2} \mathrm{O}_{2}\right)$ (A1/A2) and UVVis spectroscopy $\left(\lambda_{\max }=440 \mathrm{~nm}\right.$ and $\left.510 \mathrm{~nm}\right)(\mathbf{A 1} / \mathbf{A 2})$.

\subsection{General procedure for benzylic chlorination}

$\mathrm{NaOCl}(0.66 \mathrm{M}, 4 \mathrm{~mL})$ was added to a solution of [Mn(Salen) $\mathrm{X}]$ (2 mol\%) catalyst, tetrabutylammonium chloride (TBACl, $5 \mathrm{~mol} \%)$, substrate $(2 \mathrm{mmol})$ in dichloromethane in a $10 \mathrm{~mL}$ sealed vial. Here, TBACl acts as phase transfer catalyst and $\mathrm{NaOCl}$ is oxidant and chlorinating source. This mixture was stirred smoothly under a nitrogen atmosphere at room temperature and carried out for $12 \mathrm{~h}$. Then the reaction mixture was extracted with $\mathrm{CH}_{2} \mathrm{Cl}_{2}$ and water to remove the catalyst and unreacted $\mathrm{NaOCl}$. The solution was analyzed by GC/MS. The yield was calculated with respect to reactant added.

2.4a Benzyl chloride $(\mathbf{2 b})^{18}$ : Compound $\mathbf{2 b}$ was obtained from toluene $\mathbf{1 b}$, isolated by column chromatography (hexane/ether). ${ }^{1} \mathrm{H}$ NMR $\left(500 \mathrm{MHz}, \mathrm{CDCl}_{3}\right) \delta 7.40(\mathrm{t}, J=$ $5.4 \mathrm{~Hz}, 3 \mathrm{H}), 7.38-7.31$ (m, 2H), 4.61 (s, 2H).

2.4b 1-bromo-4-(chloroethyl)-benzene (2c): Compound 2c was obtained from 1-bromo-4-ethylbenzene 1c, isolated by column chromatography (hexane/ethyl acetate). ${ }^{1}$ HNMR (400 MHz, CDCl3) $\delta 7.48(\mathrm{~m}, 2 \mathrm{H}), 7.3(\mathrm{~m}, 2 \mathrm{H})$, $5.04(\mathrm{q}, 1 \mathrm{H}), 1.83(\mathrm{~d}, 3 \mathrm{H}) .{ }^{13} \mathrm{C} \mathrm{NMR}\left(101 \mathrm{MHz}, \mathrm{CDCl}_{3}\right) \delta$ $142.0,131.1,128.4,122.3,58.0,26.6$.

2.4c 4-(chloromethyl)-1,1'-biphenyl(2d): Compound 2d was obtained from 4-methyl-1,1'-biphenyl 1d, isolated by column chromatography (hexane/ethyl acetate). ${ }^{1} \mathrm{H}$ NMR (400 $\left.\mathrm{MHz} \mathrm{CDCl}_{3}\right) \delta$ 7.65-7.58 (m, 4H), 7.51-7.45 (m, 4H), 7.38 (ddd, $J=7.3,3.8,1.1 \mathrm{~Hz}, 1 \mathrm{H}), 4.66(\mathrm{~s}, 2 \mathrm{H}) .{ }^{13} \mathrm{C} \mathrm{NMR}$ $\left(101 \mathrm{MHz} \mathrm{CDCl}_{3}\right) \delta 141.6,140.7,136.7,129.3,129.0,127.7$, 127.7, 127.3, 46.3.

\section{4d 4'-methyl-[1,1'-biphenyl]-2-carbonitrile (2e):} Compound $\mathbf{2 e}$ was obtained from $4^{\prime}$-methyl-[1, 1' - biphenyl]2-carbonitrile 1e, isolated by column chromatography (hexane/ethyl acetate) ${ }^{1} \mathrm{H} \mathrm{NMR}\left(400 \mathrm{MHz}, \mathrm{CDCl}_{3}\right) \delta 7.77$ (d, $J=7.7 \mathrm{~Hz}, 1 \mathrm{H}), 7.72-7.61(\mathrm{~m}, 2 \mathrm{H}), 7.59-7.54(\mathrm{~m}, 2 \mathrm{H}), 7.52$ $(\mathrm{dd}, J=5.3,3.0 \mathrm{~Hz}, 2 \mathrm{H}), 7.46(\mathrm{td}, J=7.7,1.1 \mathrm{~Hz}, 1 \mathrm{H})$, 4.65 (s, 1H) ${ }^{13} \mathrm{C}$ NMR (101 MHz, $\left.\mathrm{CDCl}_{3}\right) \delta 144.9,138.4$, 138.1, 134.0, 133.1, 130.2, 129.4, 129.3, 129.1, 128.0, 126.8, 118.8, 111.4, 45.9.

2.4e (1-chloromethyl)naphthalene (2f): ${ }^{19}$ Compound 2f was obtained from 1-methyl naphthalene 1f, isolated by column chromatography (hexane/ethyl acetate). ${ }^{1} \mathrm{H}$ NMR $\left(500 \mathrm{MHz}, \mathrm{CDCl}_{3}\right) \delta 8.16(\mathrm{~d}, J=8.4 \mathrm{~Hz}, 1 \mathrm{H}), 7.88(\mathrm{dd}$, $J=17.0,8.2 \mathrm{~Hz}, 2 \mathrm{H}), 7.61(\mathrm{t}, J=7.6 \mathrm{~Hz}, 1 \mathrm{H}), 7.57-7.52$ (m, 2H), 7.47-7.41 (m, 1H), 5.07 (s, 2H).

$2.4 \mathrm{f}$ (Chloromethylene)-dibenzene (2g): Compound $\mathbf{2 g}$ was obtained from diphenyl methane $\mathbf{1 g}$, isolated by column chromatography (hexane/ethyl acetate) ${ }^{1} \mathrm{H}$ NMR (500
$\left.\mathrm{MHz}, \mathrm{CDCl}_{3}\right) \delta 7.44(\mathrm{~d}, J=7.5 \mathrm{~Hz}, 4 \mathrm{H}), 7.41-7.35(\mathrm{~m}$, $4 \mathrm{H}), 7.32(\mathrm{q}, J=7.1 \mathrm{~Hz}, 2 \mathrm{H}), 6.16(\mathrm{~s}, 1 \mathrm{H})$.

2.4g Methyl 2-(4-(1-chloro-2-methylpropyl)phenyl) propane (4): Compound 4 was obtained from ibuprofen methyl ester $\mathbf{3}$, isolated by column chromatography (hexane/ethyl acetate). ${ }^{1} \mathrm{H}$ NMR (400 $\left.\mathrm{MHz}, \mathrm{CDCl}_{3}\right) \delta{ }^{1} \mathrm{H}$ NMR (400 MHz, $\left.\mathrm{CDCl}_{3}\right) \delta$ 7.31-7.28 (m, 2H), 7.28-7.25 (m, 2H), $4.62(\mathrm{~d}, J=7.6 \mathrm{~Hz}, 1 \mathrm{H}), 3.72(\mathrm{q}, J=7.2 \mathrm{~Hz}, 1 \mathrm{H}), 3.66(\mathrm{~s}$, $3 \mathrm{H}), 2.22(\mathrm{dq}, J=13.5,6.7 \mathrm{~Hz}, 1 \mathrm{H}), 1.49(\mathrm{~d}, J=7.2 \mathrm{~Hz}$, $3 \mathrm{H}), 1.10(\mathrm{~d}, J=6.6 \mathrm{~Hz}, 3 \mathrm{H}), 0.87(\mathrm{~d}, J=6.7 \mathrm{~Hz}, 3 \mathrm{H}) .{ }^{13} \mathrm{C}$ $\mathrm{NMR}\left(101 \mathrm{MHz}, \mathrm{CDCl}_{3}\right) \delta 175.1,140.3,140.1,127.9,127.6$, 70.7, 52.3, 45.3, 36.8, 20.4, 19.7, 18.7. HRMS [ESI, (+) ve]: calcd. for (C14H19ClNaO2) 277.0962, found 277.0966.

\subsection{Preparation of oxidized $[\mathrm{Mn}(\text { salen })]^{+}$complex for ESI-MS and UV-Vis study}

In the $\mathrm{CH}_{2} \mathrm{Cl}_{2}$ solution of complex A1/A2 $\left(0.3 \times 10^{-3} \mathrm{M}\right)$, 50 fold of excess $\mathrm{NaOCl}$ was added and shaken vigorously at room temperature, after $15 \mathrm{~s}$ the color of the solution changed from orange-brown to green. Then, it was immediately subjected to UV-Vis spectroscopy. For ESI-MS study, to the $\mathrm{CH}_{2} \mathrm{Cl}_{2}$ solution of complex $\mathbf{A 1}\left(10^{-3} \mathrm{M}\right), 15$ fold of excess $\mathrm{NaOCl}$ was added and shaken vigorously for a minute at room temperature, then directly used for ESI-MS study at a different time.

\subsection{Kinetic study}

A stock solution of complex $\mathbf{A 2}\left(1.5 \times 10^{-4} \mathrm{M}\right)$ was prepared in $\mathrm{CH}_{2} \mathrm{Cl}_{2}$. To this solution 50 equivalent of excess $\mathrm{NaOCl}$ was added and shaken vigorously at $0^{\circ} \mathrm{C}$ to get the green color solution. Then $4 \mathrm{~mL}$ of this solution was taken and $1 \mathrm{mmol}$ of ethylbenzene was added and immediately subjected to timedependent UV-Vis study. The spectra were recorded in every $5 \mathrm{~s}$. The rate constant for decay of $\mathrm{Mn}(\mathrm{V})=\mathrm{O}$ complex was determined from time trace at $\lambda_{\max }, 640 \mathrm{~nm}$ which shows an exponential decay pattern. Kinetic data analysis showed that this decay followed a pseudo-first order reaction in presence of excess substrate with decay rate constant $k_{1}=4.94 \times$ $10^{-2} \mathrm{~s}^{-1}$.

\subsection{EPR study to detect the formation of $\mathrm{Mn}^{\mathrm{IV}}$ (salen) complex}

A solution of $\mathrm{Mn}^{\mathrm{III}}$ (salen) [complex $\mathbf{A 1}(10 \mathrm{mM})$ ] in $2.5 \mathrm{~mL}$ of $\mathrm{CH}_{2} \mathrm{Cl}_{2}$ was prepared. To this solution, 5 equiv. of $\mathrm{PhIO}$ was added and the solution was stirred for $5 \mathrm{~min}$. When the colour of the solution changed from brown to dark green, 10 equiv. of ethylbenzene (substrate) was added. The solution was shaken for a few seconds and an aliquot of $250 \mu \mathrm{L}$ of this solution was transferred to an EPR tube, frozen at $100 \mathrm{~K}$ and the EPR spectrum of this solution was recorded. 
Table 1. Optimization of Mn-salen catalyzed benzylic C-H chlorination.

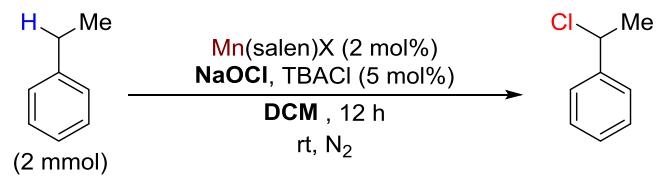

\begin{tabular}{ccccc}
\hline Entry & $\begin{array}{c}\text { NaOCl } \\
\text { amount } \\
(\mathbf{m L})\end{array}$ & $\begin{array}{c}\text { DCM } \\
\text { amount } \\
(\mathbf{m L})\end{array}$ & Yield (\%) $^{[\mathrm{a}]}$ & TON \\
\hline 1 & 0.5 & 1 & 2 & 1 \\
2 & 1 & 1 & 8 & 4 \\
4 & 1.5 & 1 & 6 & 3 \\
5 & 2 & 1 & 10 & 5 \\
6 & 2.5 & 1 & 12 & 6 \\
7 & 3 & 1 & 12 & 6 \\
8 & 3.5 & 1 & 14 & 7 \\
$\mathbf{9}$ & $\mathbf{4}$ & $\mathbf{1}$ & $\mathbf{2 8}$ & $\mathbf{1 4}$ \\
10 & 5 & 1 & 22 & 11 \\
11 & 4 & 2 & 12 & 6 \\
12 & 4 & 3 & 16 & 8 \\
13 & 4 & 4 & 17 & 8.5 \\
\hline
\end{tabular}

${ }^{\mathrm{a}}$ The yield of the product is determined by GC. TON (turn over number) for the catalyst is calculated as the mol of product formed per mol of catalyst used.

\section{Results and Discussion}

To check the efficacy of $\mathrm{Mn}$ (salen) complex towards benzylic $s p^{3} \mathrm{C}-\mathrm{H}$ chlorination, ethylbenzene was treated with $N, N$-bis(3,5-di-tert-butylsalicylidene)-1,2-cyclohexanediamino-manganese chloride $\mathbf{A 1}$ as the catalyst and aqueous $\mathrm{NaOCl}$ solution (both as oxidant and chlorinating agent) in $\mathrm{CH}_{2} \mathrm{Cl}_{2}$. For this catalytic reaction tetrabutylammonium chloride ( $\mathrm{TBACl})$ was used as phase transfer catalyst. This biphasic system afforded 1-chloroethyl benzene with turn over number (TON) 14 under a nitrogen atmosphere with time duration of $12 \mathrm{~h}$ at room temperature. Replacing the anion counterpart, $\mathrm{Mn}($ salen)Br (A2) also produced the same result. Other $\mathrm{Mn}$ (salen) complexes were found to give inferior results in comparison to either $\mathbf{A 1}$ or $\mathbf{A 2}$ (see Supporting Information). Variation of the amount of sodium hypochlorite $(\mathrm{NaOCl})$ showed that $4 \mathrm{~mL}$ of $\mathrm{NaOCl}(0.6 \mathrm{M})$ is optimal for this reaction, and lower concentration of $\mathrm{NaOCl}$ retarded the reactivity of this reaction. We also found that dilution with solvent $\mathrm{CH}_{2} \mathrm{Cl}_{2}$ had an adverse effect on this reaction (Table 1). The reaction mixtures were monitored by GC-MS and yields were determined by GC with respect to the substrate. Control reaction in absence of the $\mathrm{Mn}$ (salen) catalyst did not produce any desired product.

With optimized reaction conditions, we examined the scope of this methodology (Scheme 2). For toluene (1b) we got benzyl chloride (2b) with TON 10. Interestingly, we did not observe any chlorination on the aromatic ring. In the presence of a halide substituent (1c), the reaction proceeded smoothly to give benzylic chlorinated product (2c). The biphenyl system (1d) under the present reaction conditions afforded the respective product (2d) with a relatively high TON 16 . Even the biphenyl system containing electron withdrawing group such as cyano group (1e) was tolerated to give corresponding benzylic chlorinated product (2e). Naphthalene system (1f) also worked well to give the expected chlorinated product (2f). Diphenylmethane and isobutyl benzene were chlorinated at benzylic site ( $\mathbf{2 g}$ and $\mathbf{2 h}$ ) along with formation of some dimerized products. In case of $\alpha$-tetralone, along with benzylic chlorinated product (2i) some amount of $\alpha, \beta$-unsaturated ketone (2i') was formed in the ratio $2.5: 1$.

To demonstrate the synthetic potential of our method, we applied $\mathrm{Mn}$ (salen) chlorination method to a bioactive molecule (protected analogue). Ibuprofen methyl ester 3, a nonsteroidal anti-inflammatory drug, when subjected to this method afforded a regioselective benzylic chlorinated product 4 with $40 \%$ isolated yield (Scheme 3).

Mn-salen catalyst (A2) was characterized by X-ray crystallography (Figure 2) and ESI-MS ( $m / z=599.3)$. $\mathrm{Mn}$ (salen)X complex (A1/A2) gave an orange-brown colored solution in $\mathrm{CH}_{2} \mathrm{Cl}_{2}$ which showed an absorbance band in UV-Vis spectroscopy at $\lambda_{\max }, 440 \mathrm{~nm},\left(\varepsilon_{\max } \sim\right.$ $6.4 \times 10^{3} \mathrm{M}^{-1} \mathrm{~cm}^{-1}$ ) along with another weak band at $\lambda_{\max }, 510 \mathrm{~nm}$ (Supporting Information). ${ }^{20}$

The orange-brown color of the solution of complex A1/A2 turned to green color upon addition of an excess of oxidant aqueous $\mathrm{NaOCl}$ solution. UVVis spectrum of this solution showed a new broad absorption band around $\lambda_{\max }, 640 \mathrm{~nm}$, which indicates the formation of high-valent $\mathrm{Mn}(\mathrm{V})$-oxo species (Figure 3). ${ }^{20,21}$

Further, time-dependent UV-Vis spectra showed a gradual decrease of this band at $640 \mathrm{~nm}$ upon reaction with ethylbenzene at room temperature (Figure 4). Finally, the color of the solution changes from green to brown indicating the regeneration of the starting complex $[\mathrm{Mn}(\text { salen })]^{+}$. A kinetic analysis of disappearance of Mn-oxo species during oxidation of ethylbenzene revealed a pseudo-first order rate dependency with rate constant $k_{1}=4.9 \times 10^{-2} \mathrm{~s}^{-1}$. 


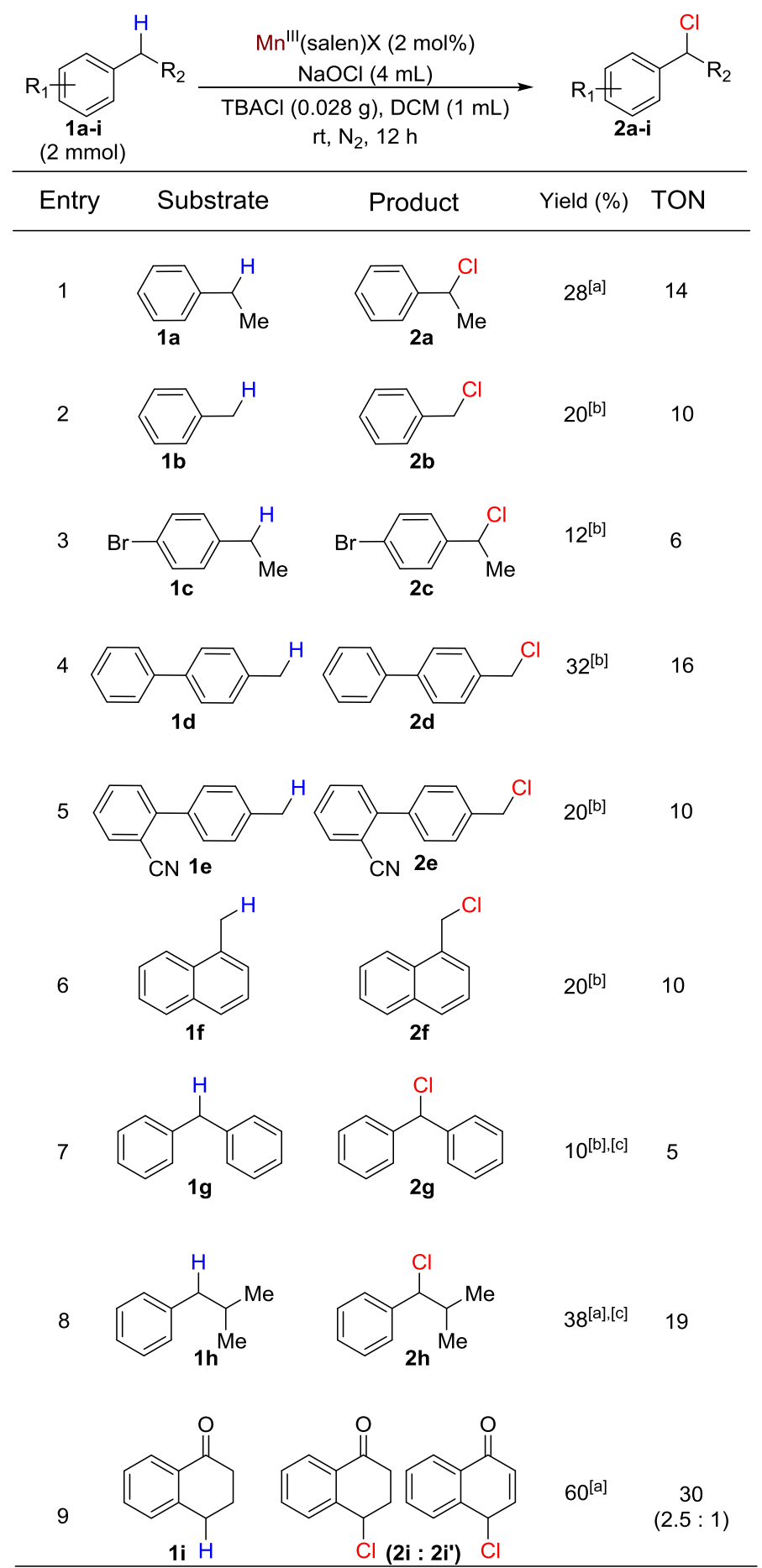

Scheme 2. Substrate scope for benzylic chlorination. TON for catalyst was calculated as the mol of product formed per mol of catalyst used. [a] yield of the product was determined by GC. [b] yield of the product was determined from isolated product. [c] $5-6 \%$ of dimerized product was formed.

Further, we conducted ESI-MS study to identify the intermediates. ${ }^{22}$ We have recorded the mass spectrum of the $\left[\mathrm{Mn}^{\mathrm{V}}(\text { salen })(\mathrm{O})\right]^{+}$prepared from a $\left[\mathrm{Mn}^{\mathrm{III}}(\text { salen })\right]^{+}$ solution in $\mathrm{CH}_{2} \mathrm{Cl}_{2}$ upon addition of excess aqueous $\mathrm{NaOCl}$. We have detected both $\left[\mathrm{Mn}^{\mathrm{V}}(\operatorname{salen})(\mathrm{O})\right]^{+}$ $(\mathrm{m} / \mathrm{z}=615.31)$ and $\left[\mathrm{Mn}^{\mathrm{IV}}(\text { salen })(\mathrm{OH})\right]^{+}(\mathrm{m} / \mathrm{z}=$ 616.33) (formed due to the hydrogen atom abstraction of $\mathrm{Mn}^{\mathrm{V}}=\mathrm{O}$ from $\mathrm{CH}_{2} \mathrm{Cl}_{2}$ ). Interestingly both the experimentally obtained spectra matched well with the simulated spectra (Figure 5). 

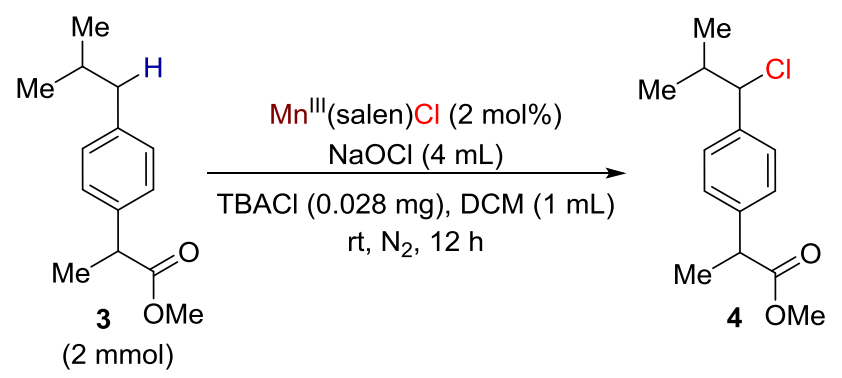

Scheme 3. Selective benzylic chlorination of ibuprofen methyl ester. Chlorination to oxidation product ratio is $4: 1$.

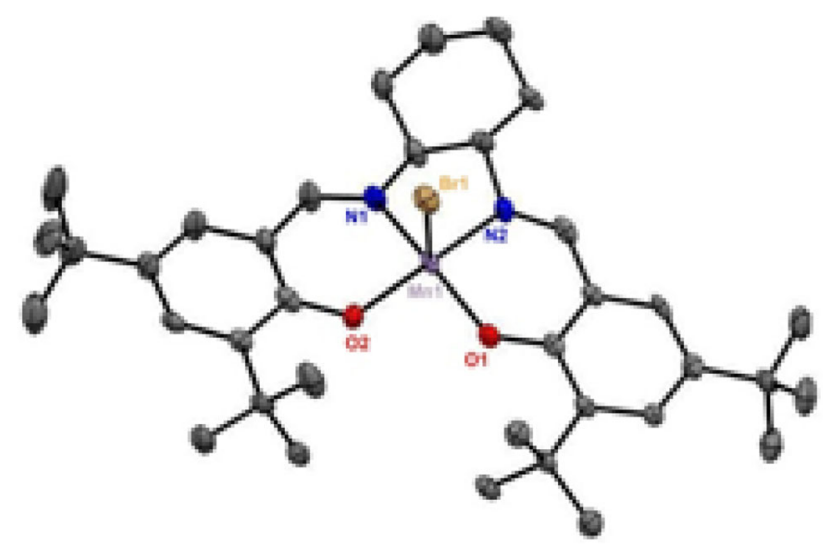

Figure 2. ORTEP diagram of $[\mathrm{Mn}($ salen $) \mathrm{Br}]$. $\mathrm{Mn}$ has square pyramidal geometry.

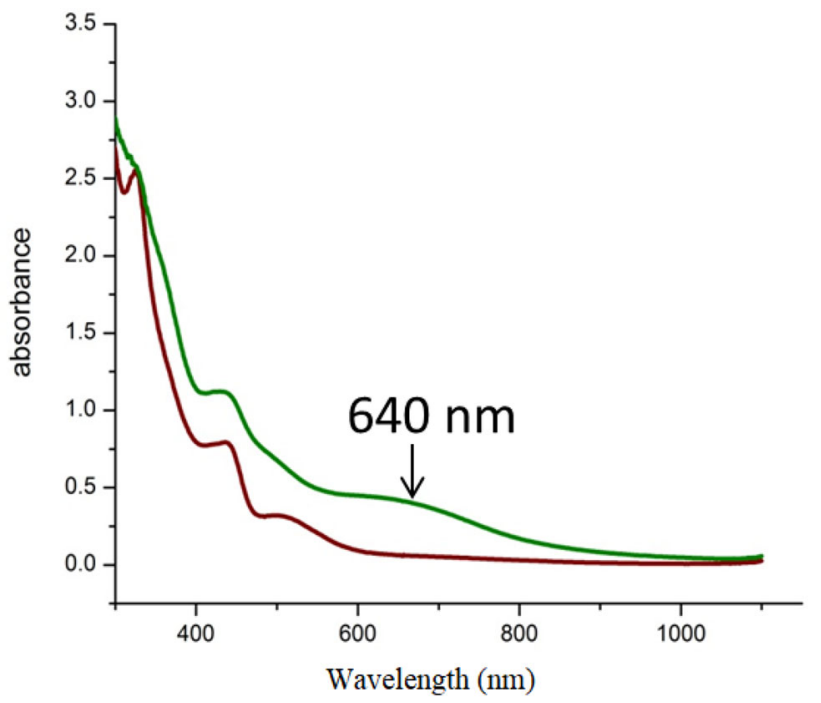

Figure 3. UV-Vis spectral changes upon addition of excess $\mathrm{NaOCl}$ into $\mathrm{CH}_{2} \mathrm{Cl}_{2}$ solution of $\mathrm{Mn}$ (salen)X (green line). $\mathrm{UV}$-Vis spectrum of $\mathrm{Mn}$ (salen) $\mathrm{X}$ in $\mathrm{CH}_{2} \mathrm{Cl}_{2}$ (red line).

We choose EPR spectroscopy for the detection of $\mathrm{Mn}^{\mathrm{IV}}$ (salen) species as $\mathrm{Mn}(\mathrm{IV})$ is a paramagnetic system ( $d^{3}$ electronic configuration) and shows wellcharacterized EPR signals, whereas $\mathrm{Mn}^{\mathrm{V}}$ and $\mathrm{Mn}^{\mathrm{III}}$

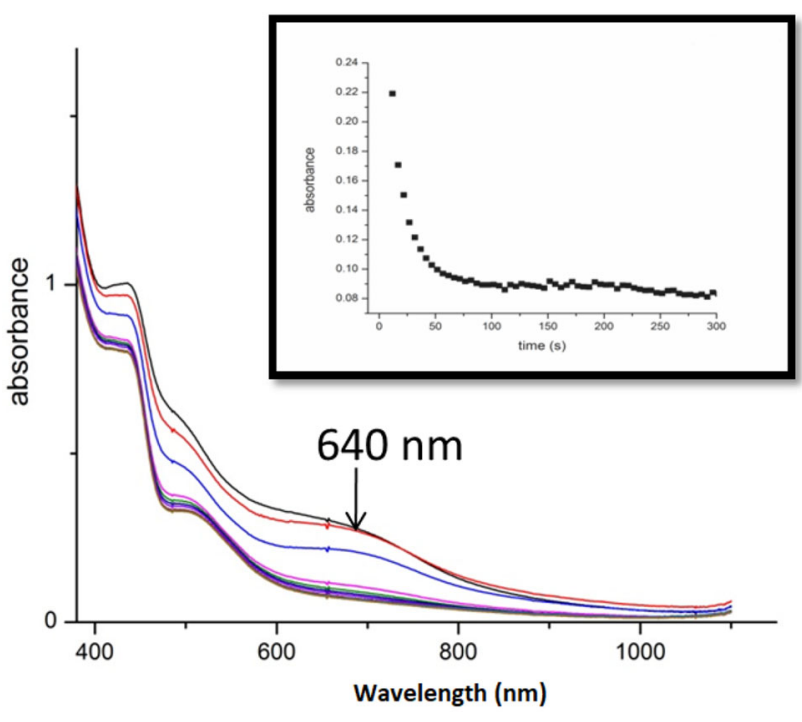

Figure 4. UV-Vis spectral changes during oxidation of ethylbenzene. Inset: Decay of absorption at $640 \mathrm{~nm}$.

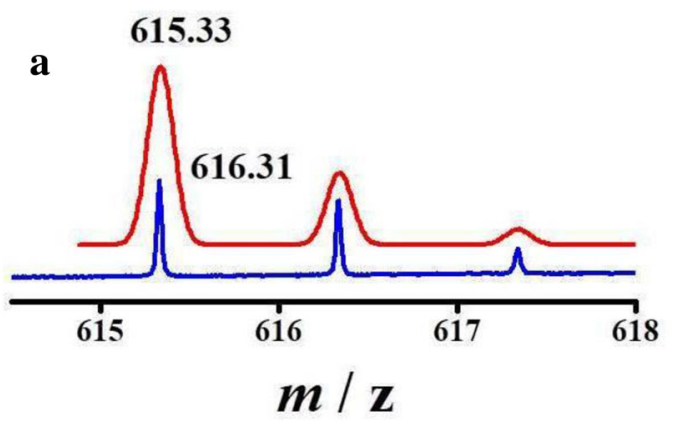

b $\quad 616.35$

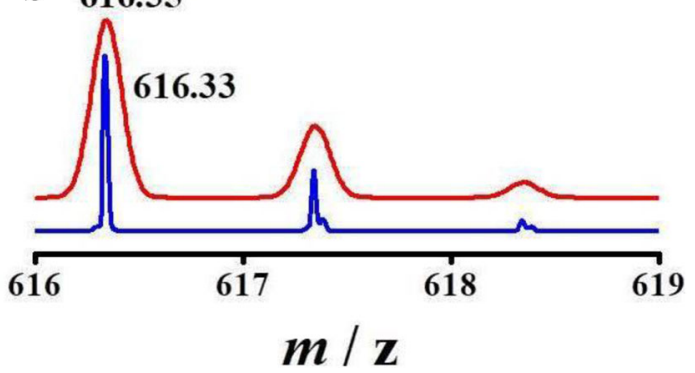

Figure 5. (a) ESI-MS spectrum of $\left[\mathrm{Mn}^{\mathrm{V}} \text { (salen)(O) }\right]^{+}$; (b) ESI-MS spectrum of $\left[\mathrm{Mn}^{\mathrm{IV}}(\text { salen })(\mathrm{OH})\right]^{+}$(experimental (blue) and simulated (red)).

complexes are EPR-silent at the usual X-band frequencies. ${ }^{22}$ For the EPR study, a $10 \mathrm{mM}$ solution of $\mathrm{Mn}^{\mathrm{III}}$ (salen) in $\mathrm{CH}_{2} \mathrm{Cl}_{2}$ was prepared, subsequently, 5 equiv. of $\mathrm{PhIO}$ was added which generated green color of $\mathrm{Mn}^{\mathrm{V}}=\mathrm{O}$ species. Then 10 equiv. of ethylbenzene was added to this solution (noteworthy, the resulting solution provided $\mathrm{C}-\mathrm{H}$ oxidation product of ethylbenzene, 1-phenylethanol and acetophenone via HAA step). This solution displays an EPR spectrum with $g$ values 


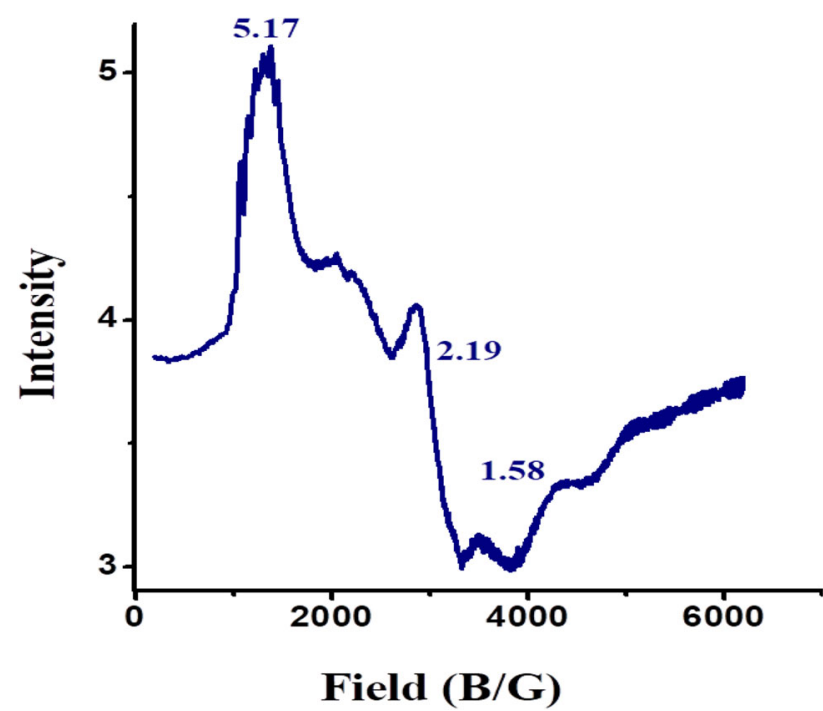

Figure 6. X-band EPR spectra of the $\mathrm{Mn}^{\mathrm{IV}}$ (salen) complexes in $\mathrm{CH}_{2} \mathrm{Cl}_{2}$ at $100 \mathrm{~K}$ (frequency $9.5 \mathrm{GHz}$ ) generated from the $\mathrm{Mn}^{\mathrm{III}}$ (salen) $\mathrm{Cl}$ complex $\mathbf{A 1}+\mathrm{PhIO}$ (5 equiv.) + ethylbenzene (10 equiv.).

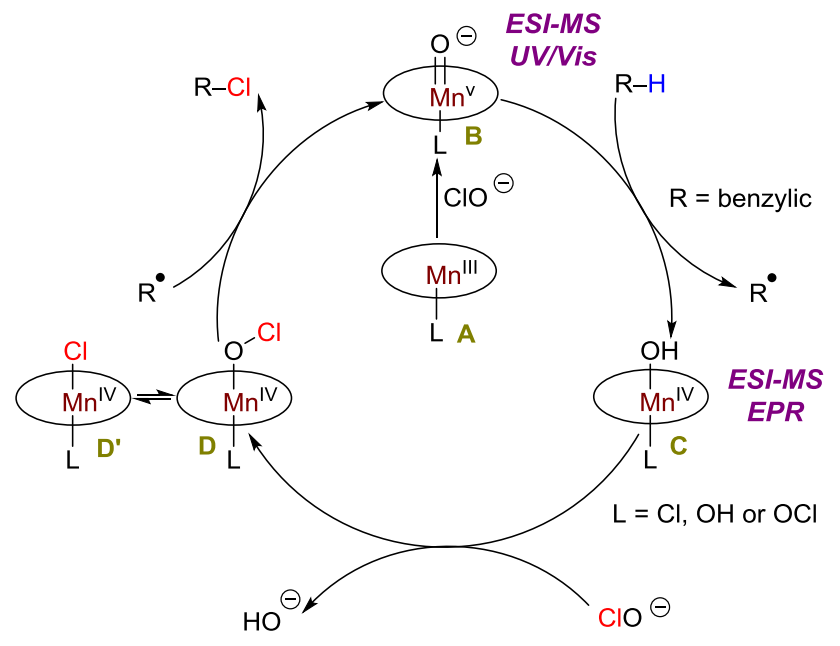

Figure 7. Proposed mechanistic cycle.

of 5.17, 2.19 and 1.58 implicating the formation of a $\mathrm{Mn}^{\mathrm{IV}}$ intermediate during manganese salen-catalyzed benzylic chlorination. These $\mathrm{g}$ values are characteristic of a $d^{3} \mathrm{Mn}^{\mathrm{IV}}$-system with $\mathrm{S}=3 / 2$ which arise from the $\mathrm{ms}= \pm 1 / 2$ with rhombic symmetry. ${ }^{21,23}$ The signal at $g=5.17$ also displays six-line hyperfine splitting as expected for $\mathrm{I}=5 / 2$ of ${ }^{55} \mathrm{Mn}$ nucleus (Figure 6).

In the absence of ethylbenzene, we got similar EPR signals under the same experimental condition. This can be addressed by the proton abstraction of $\mathrm{Mn}^{\mathrm{V}}=\mathrm{O}$ species (generated upon addition of $\mathrm{PhIO}$ to $\mathrm{Mn}^{\mathrm{III}}$ (salen) $\mathrm{Cl}$ in $\mathrm{CH}_{2} \mathrm{Cl}_{2}$ ) from solvent $\mathrm{CH}_{2} \mathrm{Cl}_{2}$.

Based on our initial mechanistic studies and literature reports, ${ }^{24}$ we propose a catalytic cycle for the chlorination (Figure 7). The Mn-catalyst (A) is first oxidized by basic $\mathrm{NaOCl}$ to form $\mathrm{Mn}^{\mathrm{V}}=\mathrm{O}(\mathbf{B})$ complex (supported by ESI-MS and UV/Vis), which then abstracts hydrogen from substrate generating free benzyl radical and $\mathrm{Mn}^{\mathrm{IV}}$ $\mathrm{OH}$ (C) complex (supported by ESI-MS and EPR). For a few substrates (isobutylbenzene, diphenylmethane), the formation of dimerized products indicates the formation of a stable benzyl radical. Then $\mathrm{Mn}^{\mathrm{IV}}-\mathrm{OCl}$ (D) is being generated from $\mathrm{Mn}^{\mathrm{IV}}-\mathrm{OH}$ by ligand exchange with $\mathrm{NaOCl}$. In the next step, benzyl radical abstracts chlorine from $\mathrm{Mn}^{\mathrm{IV}}-\mathrm{OCl}$ to form chlorinated product and regenerate $\mathrm{Mn}^{\mathrm{V}}=\mathrm{O}$ complex.

\section{Conclusions}

In summary, we report a method for benzylic $\mathrm{C}-\mathrm{H}$ chlorination catalyzed by easily synthesizable and tunable $\mathrm{Mn}$-(salen) complex where cheap $\mathrm{NaOCl}$ has been used as the chlorinating agent. Here, we are proposing that the reaction is passing through an $\mathrm{Mn}(\mathrm{V})=\mathrm{O}$ species which can abstract a hydrogen atom from substrate generating benzylic radical. The formation of high-valent manganese species is supported by ESI-MS and UV-Vis studies. A further development of this methodology can accomplish late-stage derivatization of various bioactive molecules containing benzylic site.

\section{Supplementary Information (SI)}

All additional information, ${ }^{1} \mathrm{H}$ NMR, ${ }^{13} \mathrm{C}$ NMR, Mass and GC-MS spectral data for the characterization of compounds are given in the Supporting Information. Supplementary Information is available at www.ias.ac.in/chemsci.

\section{Acknowledgements}

This activity is supported by SERB, India (EMR/2015/ 000164). Financial support has been received from CSIRIndia (Fellowship to S.R.).

\section{References}

1. (a) Vaillancourt F H, Yeh E, Vosburg D A, Tsodikova S G and Walsh C T 2006 Nature's inventory of halogenation catalysts: Oxidative strategies predominate Chem. Rev. 106 3364; (b) Fujimori D G and Walsh C T 2007 What's new in enzymatic halogenations Curr. Opin. Chem. Biol. 11 553; (c) Rittle J and Green M T 2010 Cytochrome P450 compound I: Capture, characterization, and $\mathrm{C}-\mathrm{H}$ bond activation kinetics Science 330 933; (d) Krebs C, Fujimori D G, Walsh C T and Bollinger J 2007 NonHeme Fe(IV)-Oxo intermediates Acc. Chem. Res. 40 484; (e) Holm R H, Kennepohl P and Solomon E I 1996 Structural and functional aspects of metal sites in biology Chem. Rev. 96 2239; (f) Sono M, Roac M P, Coulte E D and Dawson J H 1996 Heme-containing oxygenases 
Chem. Rev. 96 2841; (g) Cook S A, Hill E A and Borovik A S 2015 Lessons from nature: A bio-inspired approach to molecular design Biochemistry 54 4167; (h) Que L Jr 201760 years of dioxygen activation J. Biol. Inorg. Chem. 22 171; (i) Huang X and Groves J T 2017 Beyond Ferryl-mediated hydroxylation: 40 Years of the rebound mechanism and $\mathrm{C}-\mathrm{H}$ activation J. Biol. Inorg. Chem. 22 185

2. (a) Yosca T H, Rittle J, Krest C M, Onderko E L, Silakov A, Calixto J C, Behan R K and Green M T 2013 Iron(IV)hydroxide $\mathrm{pKa}$ and the role of thiolate ligation in $\mathrm{C}-\mathrm{H}$ bond activation by cytochrome $\mathrm{P} 450 \mathrm{Sci}$ ence 342 825; (b) Green M T, Dawson J H and Gray H B 2004 Oxoiron(IV) in chloroperoxidase compound II is basic: implications for P450 chemistry Science 304 1653; (c) Stone K L, Behan R K and Green M T 2005 $\mathrm{X}$-ray absorption spectroscopy of chloroperoxidase compound I: Insight into the reactive intermediate of P450 chemistry Proc. Natl. Acad. Sci. U.S.A. 102 16563; (d) Wagenknecht H A and Woggon W D 1997 Identification of intermediates in the catalytic cycle of chloroperoxidase Chem. Biol. 4367

3. (a) Groves J T 2005 In Cytochrome P450: Structure, mechanism and biochemistry Paul R Ortiz de Montellano (Ed.) (New York: Springer-US) p.1; (b) Kellner D G, Hung S C, Weiss K E and Sligar S G 2002 Kinetic characterization of compound I Formation in the thermostable cytochrome P450 CYP119 J. Biol. Chem. 277 9641; (c) Schlichting I, Berendzen J, Chu K, Stock A M, Maves S A, Benson D E, Sweet R M, Ringe D, Petsko G A and Sligar S G 2000 The catalytic pathway of cytochrome p450cam at atomic resolution Science $\mathbf{2 8 7}$ 1615; (d) Egawa T, Shimada H and Ishimura Y 1994 Reaction of ferric cytochrome P450cam with peracids: Kinetic characterization of intermediates on the reaction pathway Biochem. Biophys. Res. Commun. 2011464

4. (a) Chen Q and Li K 2014 Process for the preparation of benzoyl chloride from toluene, chlorine and benzoic acid China patent CN103787874 A; (b) Ding L, Tang J, Cui M, Bo C, Chen X and Qiao X 2011 Optimum design and analysis based on independent reaction amount for distillation column with side reactors: Production of benzyl chloride Ind. Eng. Chem. Res. 5011143

5. Kimbrough R D and Bramlbtt R N 1969 Phosphorus pentachloride for the replacement of benzylic hydrogen with chlorine J. Org. Chem. 343655

6. Dutta R L and Fernandas F V 1914 Chlorination by means of aqua regia. The chlorination of benzene, thiophene, toluene and mesitylene J. Am. Chem. Soc. 361007

7. Kojima T, Matsuo H and Matsuda Y 1998 A novel and highly effective halogenation of alkanes with halides on oxidation with m-chloroperbenzoic acid: Looks old, but new reaction Chem. Lett. 271085

8. Kajigaeshi S, Kakinami T, Moriwaki M, Tanaka T and Fujisaki S 1988 An effective chlorinating agent benzyltrimethylammonium tetrachloroiodate, benzylic chlorination of alkylaromatic compound Tetrahedron Lett. 295783

9. Liu S, Zhang Q, Li H, Yang Y, Tian X and Whiting A 2015 A visible-light-induced $\alpha-\mathrm{H}$ chlorination of alkylarenes with inorganic chloride under NanoAg@ $\mathrm{AgCl}$ Chem. Eur. J. 219671
10. (a) Kenner J 1945 Oxidation and reduction in chemistry Nature 156 369; (b) Walling C and Jacknow B B 1960 Positive halogen compounds. I. The radical chain halogenation of hydrocarbons by t-butyl hypochlorite J. Am. Chem. Soc. 826108

11. (a) Che C M, Lo V K Y, Zhou C Y and Huang J S 2011 Selective functionalisation of saturated C$\mathrm{H}$ bonds with metalloporphyrin catalysts Chem. Soc. Rev. 40 1950; (b) Meunier B, Visser S P D and Shaik S 2004 Mechanism of oxidation reactions catalyzed by cytochrome P450 enzymes Chem. Rev. 104 3947

12. (a) Bernard M 1992 Metalloporphyrins as versatile catalysts for oxidation reactions and oxidative DNA cleavage Chem. Rev. 92 1411; (b) Bernadou J, Fabiano A S, Robert A and Meunier B 1994 "Redox Tautomerism" in highvalent metal-oxo-aquo complexes. Origin of the oxygen atom in epoxidation reactions catalyzed by water-soluble metalloporphyrins J. Am. Chem. Soc. 116 9375; (c) Balahura R J, Sorokin A, Bernadou J and Meunier B 1997 Origin of the oxygen atom in $\mathrm{C}-\mathrm{H}$ bond oxidations catalyzed by a water-soluble metalloporphyrin Inorg. Chem. 363488

13. (a) Liu W and Groves J T 2010 Manganese porphyrins catalyze selective $\mathrm{C}-\mathrm{H}$ bond halogenations J. Am. Chem. Soc. 132 12847; (b) Liu W, Huang X, Cheng M J, Nielsen R J, Goddard W A and Groves J T 2012 Oxidative aliphatic $\mathrm{C}-\mathrm{H}$ fluorination with fluoride ion catalyzed by a manganese porphyrin Science 337 1322; (c) Huang X, Liu W, Ren H, Neelamegam R, Hooker J M and Groves J T 2014 Late stage benzylic C-H fluorination with $\left[{ }^{18} \mathrm{~F}\right]$ fluoride for PET imaging J. Am. Chem. Soc. 136 6842

14. (a) Jacobsen EN 1993 In Catalytic Asymmetric Synthesis Ojima I (Ed.) (New York: VCH) p. 159; (b) Jacobsen E N 2000 Asymmetric Catalysis of Epoxide Ring-Opening Reactions Acc. Chem. Res. 33 421; (c) Zhang W, Loebach J L, Wilson S R and Jacobsen E N 1990 Enantioselective Epoxidation of Unfunctionalized Olefins Catalyzed by Salen manganese complexes J. Am. Chem. Soc. 112 2801; (d) Irie R, Noda K, Ito Y and Katsuki T 1991 The Use of Chiral Sulfides in Catalytic Asymmetric Epoxidation Tetrahedron Lett. 32 1055; (e) McGarrigle E M and Gilheany D G 2005 Chromium- and Manganesesalen Promoted Epoxidation of Alkenes Chem. Rev. 105 1563

15. (a) Huang X, Bergsten T M and Groves J T 2015 Manganese-catalyzed late-stage aliphatic $\mathrm{C}-\mathrm{H}$ azidation J. Am. Chem. Soc. 137 5300; (b) Liu W and Groves J T 2013 Manganese-catalyzed oxidative benzylic C-H fluorination by fluoride ions Angew. Chem. Int. Ed. 52 6024; (c) Liu W and Groves J T 2015 Manganese catalyzed C-H halogenation Acc. Chem. Res. 481727

16. (a) Chidambaram M, Sonavane S U, Zerda J D L and Sasson Y 2007 Didecyldimethylammonium bromide (DDAB): A universal, robust, and highly potent phase-transfer catalyst for diverse organic transformations Tetrahedron 63 7696; (b) Godajdar B M and Ansari B 2015 Preparation of novel magnetic dicationic ionic liquid polymeric phase transfer catalyst and their application in nucleophilic substitution reactions of benzyl halides in water J. Mol. Liq. 20234 
17. Collman J P, Zeng L and Braumanb J I 2004 Donor ligand effect on the nature of the oxygenating species in $\mathrm{Mn}^{\mathrm{III}}$ (salen)-catalyzed epoxidation of olefins: Experimental evidence for multiple active oxidants Inorg. Chem. $\mathbf{4 3} 2672$

18. Zhao M and Lu W 2017 Visible light-induced oxidative chlorination of alkyl sp ${ }^{3} \mathrm{C}-\mathrm{H}$ bonds with $\mathrm{NaCl} /$ Oxone at room temperature Org. Lett. 194560

19. Malapit C A, Ichiishi N and Sanford M S 2017 Pdcatalyzed decarbonylative cross-couplings of aroyl chlorides Org. Lett. 194142

20. (a) Feth M P, Bolm C, Hildebrand J P, Köhler M, Beckmann $\mathrm{O}$, Bauer M, Ramamonjisoa $\mathrm{R}$ and Bertagnolli $\mathrm{H}$ 2003 Structural investigation of high-valent manganesesalen complexes by UV/Vis, Raman, XANES, and EXAFS spectroscopy Chem. Eur. J. 91348

21. Kurahashi T, Kikuchi A, Tosha T, Shiro Y, Kitagawa T and Fujii H 2008 Transient intermediates from Mn(salen) with sterically hindered mesityl groups: Interconversion between $\mathrm{Mn}^{\mathrm{IV}}$-phenolate and $\mathrm{Mn}^{\mathrm{IIII}}$-phenoxyl radicals as an origin for unique reactivity Inorg. Chem. 471674
22. Adam W, Mock-Knoblauch C, Saha-Möller C R and Herderich M 2000 Are $\mathrm{Mn}^{\mathrm{IV}}$ species involved in $\mathrm{Mn}$ (Salen)-catalyzed Jacobsen-Katsuki epoxidations? A mechanistic elucidation of their formation and reaction modes by EPR spectroscopy, mass-spectral analysis, and product studies: Chlorination versus oxygen transfer J. Am. Chem. Soc. 1229685

23. Leto D F, Massie A A, Colmer H E and Jackson T A 2016 $\mathrm{X}$-Band electron paramagnetic resonance comparison of mononuclear MnIV-oxo and MnIV-hydroxo complexes and quantum chemical investigation of MnIV zero-field splitting Inorg. Chem. 553272

24. (a) Volz H and Müller W 1997 Isolation and characterization of a porphinatomanganese(IV) complex from the reaction of dichloro monoxide with 5,10,15,20-Tetrakis(2,6-dichloropheny)porphinatomanganese(III) chloride [Mn(EDCPP)CI] Chem. Ber./Recueil 130 1099; (b) Chen F C, Cheng S H, Yu C H, Liu M H and Su O 1999 Electrochemical characterization and electrocatalysis of high valent manganese meso-tetrakis(N-methyl-2pyridyl)porphyrin J. Electroanal. Chem. 47452 